\title{
DESIGN AND DEVELOPMENT OF AN LADM-BASED EXTERNAL DATA MODEL FOR LAND REGISTRY AND CADASTRE TRANSACTIONS IN TURKEY: A CASE STUDY OF TREASURY REAL PROPERTIES
}

\author{
Projeto e desenvolvimento de um modelo de dados externos baseado em \\ LADM para registro de terras e transações de cadastro na Turquia: um \\ estudo de caso de propriedades reais de Tesouro \\ Mehmet Alkan ${ }^{1}$ - ORCID: 0000-0002-7542-5455 \\ Elif Taş Arslan² - ORCID: 0000-0002-4710-8030
}

${ }^{1}$ Yıldız Technical University, Geomatics Department, İstanbul, Turkey.

E-mail: alkan@yildiz.edu.tr

${ }^{2}$ istanbul Greater Municipality, Beyoglu, Istanbul, Turkey.

E-mail: eliftas.ytu10@yahoo.com

Received in $1^{\text {th }}$ March 2020

Accepted in $29^{\text {th }}$ November 2020

\section{Abstract:}

The processes starting with the identification and registration of treasury properties have an essential place in the cadastral systems. Spatial data modelling studies were conducted in 2002 to establish a common standard structure on the fundamental similarities of land management systems. These studies were stated as a beginning named Core Cadastral Domain Model (CCDM), since 2006, it has been started to be made under the name of LADM. This model was accepted in 2012 as a standard model in the field of land administration by the International Organization for Standardization (ISO). In this study, an external model class is proposed for LADM's transactions related to Treasury's real estates properties which are related National Property Automation Project (MEOP). In order to determine the deficiency of this current external model, databases containing records related to spatial data and property rights were examined, and the deficiencies related to transactions on treasury properties were determined. The created external class is associated with the LADM's LA_Party, LA_RRR, LA_SpatialUnit and LA_BAUnit master classes. Herewith the standardization of the external data model is ensured. If the external model is implemented by the responsible standardization of the archiving processes will be more comfortable and faster to register.

Keywords: Land Administration Domain Model (LADM), Unified Modelling Language (UML), external data model, object oriented-modelling, Directorate General of National Property

\section{Resumo:}

Os processos que se iniciam na identificação e registo de bens do tesouro têm um lugar essencial nos sistemas cadastrais. Estudos de modelagem de dados espaciais foram conduzidos em 2002 para estabelecer uma estrutura

How to cite this article: ALKAN, M.; ARSLAN, E.T. Design and Development of an LADM-Based External Data Model for Land Registry and Cadastre Transactions in Turkey: A Case Study of Treasury Real Properties. Bulletin of Geodetic Sciences. 27(1): e2021004, 2021. 
padrão comum sobre as semelhanças fundamentais dos sistemas de gestão da terra. Esses estudos foram declarados como um início denominado Core Cadastral Domain Model (CCDM), desde 2006, passou a ser feito com o nome de LADM. Este modelo foi aceito em 2012 como um modelo padrão na área de administração de terras pela International Organization for Standardization (ISO). Neste estudo, uma classe de modelo externo é proposta para as transações do LADM relacionadas a propriedades imobiliárias do Tesouro que estão relacionadas ao Projeto de Automação Imobiliária Nacional (MEOP). Para apurar a deficiência do atual modelo externo, foram examinadas bases de dados contendo registros relativos a dados espaciais e direitos de propriedade e apuradas as deficiências relacionadas a transações com bens do tesouro. A classe externa criada está associada às classes master LA_Party, LA_RRR, LA_SpatialUnit e LA_BAUnit do LADM. Com isso, a padronização do modelo de dados externo é garantida. Se o modelo externo for implementado pelo responsável pela padronização dos processos de arquivamento ficará mais confortável e rápido de se cadastrar.

Palavras-chave: Modelo de Domínio de Administração de Terras (LADM), Linguagem de Modelagem Unificada (UML), modelo de dados externos, modelagem orientada a objetos, Diretoria Geral de Propriedade Nacional

\section{Introduction}

The concept of land management was introduced by the United Nations Economic Commission for Europe in the early 1990s and is considered a new expression in this field. The United Nations Economic Commission for Europe defines the concept of land administration as the creation, processing and presentation of land-related value, use and ownership information during the implementation of land management policies. Land administration according to Dale and McLaughlin (1999); These are the processes related to following the changes in the land and real estates, making regulations regarding the use and protection of the real estate, obtaining income from the real estate and the ownership and usage status of the land. According to Dale and McLaughlin's (1998) definition, land management includes preventing the deterioration of the natural habitat, ensuring efficient use of land resources. Also, it supports the growing population, managing underground resources such as sewage, water, providing equal access to real estate market-related returns, taxing on real estates. And the processes of controlling the fees and managing the policies related to all these issues (UNECE, 1996; UNECE, 2004; Dale and McLaughlin, 1999; Dale and McLaughlin, 1998).Although the land management systems in the world are different and, various scientific activities are carried out within the land administration, and this system has been limited in many areas around the world. In 2002, Oosterom and Lemmen took steps on spatial data modelling to establish a common standard, taking into account similar characteristics of land management (Oosterom and Lemmen, 2002). These studies were initially named as the Basic Cadastral Model but were later carried out under the name LADM in collaboration with the International Federation of Surveyors (FIG). The main objective of LADM is to prevent the repetition of similar studies and to contribute to the active development of land management systems based on the developed model. Besides, the other aim of LADM is to enable them to use the standard structure required by the model in the studies conducted in the design and development of land management systems in the same or different countries of the world. While developing the model, attention is paid to complying with the basic principles of cadastre 2014 vision (Kaufmann and Steudler, 1998), evaluating the common aspects of land management systems developed around the world and making the model as simple and understandable as possible (Alkan and Polat, 2017; Alkan and Sürmeneli, 2017; Oosterom et al., 2006-a; Oosterom et al., 2006-b).

After Oosterom and Lemmen, the LADM model has continued to be developed by discussing many scientific studies (Oosterom and Lemmen, 2002; Oosterom et al., 2006-a; Oosterom et al., 2006-b; Oosterom et al., 2006-a; Lemmen and Oosterom, 2003; Lemmen et al., 2003; Molen et al., 2004). Together with these scientific studies leading to LADM, LADM was accepted as an international standard in 2012 and became ISO 19152 (Land Administration Domain Model - LADM). 
In LADM, the targets can be listed as follows; a- description of cadastral objects, b- characteristics of cadastral objects, c- relations with other objects and how these relations are, $d$ - when and under what conditions a cadastral object exists and under which circumstances will not leave any questions known as the information is not (Alkan, 2005; Polat and Alkan, 2018; Coruhlu and Yıldız, 2018; Coruhlu et. al,2017; Steudler, 2003).

Since LADM is accepted as an International Organization for Standardization (ISO) standard, studies have been started to be applied to the land management structure in Turkey as well as the studies carried out worldwide. For example, intrigue (Cete, 2008) in his doctoral dissertation "A land administration system for Turkey" has made recommendations for the improvement and refers to land administration standards in this area. Aydinoglu in his doctoral dissertation "of geographic data exchange model for Turkey to be a developing" LADM had worked for and focused. Döner (2010) examined LADM's support for 3D cadastre in his PhD thesis entitled Three Dimensional Approach for Turkish Cadastral System. Inan (2010) developed a spatial data model compatible with LADM in his doctoral dissertation by considering the agricultural structure in our country in terms of land administration. Polat (2018) developed an LADM External class for transferring and modelling of the documents used in the land registry and cadastre transactions between the land registry system and other institutions involved in the deed and cadastral transactions in his PhD study titled I Design and Application of External Data Model for Land Registry and Cadastre Operations in Land Management. Özçelik has developed a positional data model in line with the LADM for unique agricultural products in our country. Inan and Yomralioglu (2011) examined LADM and proposed spatial modelling for land management in Turkey. Cete and Inan (2013) Considering the LADM studies have highlighted the importance of Turkey for cadastre. Aydinoglu and Inan in their work by developing a land registry and cadastre data model based on Land Registry and Cadastre Information System (TAKBIS) and Turkey's National Geographical Information System (TUCBS) they associate with the project. Cagdas et al. (2016) developed a data model that regulates valuation activities and taxation processes based on LADM. Taş and Çağdaş (2018) proposed many additions to the LADM Appraisal Model for the establishment of sales prices register. Alkan and Polat (2017-a-b) proposed an LADM for Turkey in work associated with the base class. Alkan and Polat (2017-a-b) discussed the LADM's view of the cadastral aspects of spatial and temporal changes through scientific publications.

In this study, the main objective is to model each transaction performed on treasury properties through data sets within a system. The main objective is based on three sub-sections. These subsections;

(1) To be trace with the works realised in the field of land administration at national and international level and to make inferences,

(2) To identify new geographic information systems that will facilitate life by examining information systems containing data records on ownership at the national level,

(3) To design a data model associated with LADM to establish a standard in the management of external documents used in transactions on treasury properties.

With the external data model developed concerning LADM,

- Transactions on treasury properties will have a standard structure.

- Temporary and qualitative analysis of treasury properties will be made. Thus it will increase process flow and shareability.

\section{The Numbering of the Study}

This paper describes how to model each transaction is performed on treasury properties through data sets within a system. In this study, firstly, literature review was carried out. Subsequently, the requirements of the Analysis, Creation of the External Data Model, Associating the External Data Model with the LADM are explained. 
Contracts, directives and promissory notes to be used in the design of the external data model are examined in the Requirement Analysis section. Based on this review, the attribute data and the types of these data that should be in the standard to be proposed are determined. In the Creation of External Data Model section, an external data model was designed according to the data obtained from the information and documents. The external data model, which is also designed in the Association of External Data Model with LADM, is associated with the basic classes of LADM. Thus, the logical data model of the aimed model was created. As a result, the product, the conceptual data model, was developed based on LADM. Throughout this design approach, Unified Modelling Language (UML) diagrams, along with textual and graphical descriptions, were used for the representation of all activities, processes, classes, attributes and associations. In this study, the key to address this complexity, as well as a constant change in data. That is to work with standards and conceptual data models. The conceptual data models have been defined and represented in section four.

\section{Transactions Related to LADM and Treasures in Turkish Cadastral System}

The Core Cadastral Domain Model (CCDM) was first proposed during the development of the Land Management Basic Model (LADM) (Alkan and Polat, 2016; Oosterom and Lemmen, 2002; Oosterom et al., 2006-b). Three main classes represent the Basic Cadastre Model. These are the RegistrationObject, Person, and RRR (Rights, Restrictions and Responsibility) base classes. There are also abstract classes in the model that do not correspond to the object. The main function of the model is to record and represent the interaction between an object (RegisterObject) recorded in connection with the land and the persons (Person: Person) who are in a legal or traditional relationship with these objects by registering them through rights, restrictions and responsibilities (RRR) (Oosterom et al., 2006a; Oosterom et al., 2006-b; Yomralığlu et al., 2007). As pointed out from this model, there is no direct connection between the RecordObject and the Person. The RRR class provides a connection between these two classes. This class provide the benefit of recognizing multiple rights, limitations and responsibilities between the Person and the RegistrationObject.

Different versions of the Basic Cadastre Model were developed and subject to scientific meetings between 2002-2006. In 2006, it was named FIG Core Cadastral Domain Model in Munich. Then, the first steps of standardization studies were taken between 2006-2008 with the activities of FIG, ISO / TC211, Joint Research Center of the European Commission (JRC), United Nations Human Settlements Program (UN-HABITAT). As a result of the studies, it was proposed that the model be accepted as a standard by ISO and as a result of voting, it was accepted as the standard with the name 'ISO 19152: 2012 LADM (Land Administration Domain Model) (Polat, 2018).

The LADM FeatureType, CodeList, DataType, and Enumeration are built on basic UML profiles. LADM consists of the following classes;

(1) LA_Party representing people

(2) LA_RRR representing ownership, limitations and responsibilities established on objects registered in the land management system

(3) LA_BAUnit representing objects registered in the land management system

(4) Consists of LA_SpatialUnit classes representing the positional properties of objects not registered in the land management system (Yomralıoğlu et al., 2007; Doner, 2010; İnan, 2010). 


\subsection{Transactions Related to Treasury Real Estate}

In this section, the transactions made on real estate properties owned by the Treasury are explained.

\subsubsection{General Directorate of National Real Estate}

It is the institution which makes transactions such as the sale of the real estate in private ownership of the treasury, exchange of land, construction in exchange for land or floor, renting, pre-permitting and establishing easement rights and renting of the places under the provisions and savings of the State. The valuation criteria for the determination of the personnel by the Ministry of Finance and other real estates determined by this Ministry to determine the criteria for valuation transactions to be made by the same personnel, to ensure the standardization of valuation, to develop standards, principles, methods and techniques for the valuation of prices and to be monitored in the real estate valuation in order to determine the principles and procedures, Circular No. 2014/1 was issued by the Ministry of Finance General Directorate of National Real Estate (Sevük and Beceren, 2017).

The function of the General Directorate of National Real Estate (GDNRE) within the scope of its mission and vision is to meet the real estate support required for both public services and public and private investments with a fee / free of charge, to contribute to the improvement of rural and urban quality of life with budget support by increasing the efficiency in the administration of Treasury real estate.

Central organization; General Manager consists of four Assistant General Managers, 21 Department Heads and 8 Branch Directorates. The provincial organization consists of the National Real Estate Department or Real Estate / National Real Estate Directorates in the provinces, according to the intensity of the national real estate business and transactions, and the Real Estate / National Real Estate Services within the National Real Estate Directorate or Financial Office in the districts.

\section{Modelling of Transactions Related to the Treasury under the Scope of LADM}

In this section, the spatial database design will be performed based on the operations of the external model defined in section 2. In this context, this section consists of the sub-sections "Requirements Analysis", "Creating an External Data Model", and "Associating the External Data Model with LADM". In the "Requirements Analysis" section, contracts, directives and notes to be used in the design of the external data model are examined. Based on this review, the attribute data and the types of these data that should be present in the standard to be proposed were decided. In this section, an external data model is designed according to the data obtained from information and documents. Associating the External Data Model with LADM is also carried out in this section, and the designed external data model is associated with the LADM base classes.

\subsection{Requirement Analysis}

In order to model the transactions carried out on the real estate properties of the Treasury based on LADM, the National Real Estate Processing Directive, which is available on the website of the GDNRE, and the specifications and contracts presented in this directive were used. These specifications and contracts, sales specifications, instalment sales agreement, lease specifications, lease agreement, real estate determination report, adequate pay notice, pre-permit specification, pre-authorization agreement, easement agreement, use right and concession agreement, concession right and concession agreement. 
Each information requested in the directives, contracts and specifications used in modelling is included as attribute data of the classes in the model. The aim is to store the documents created by different institutions used for the execution of a transaction in a single database following standards and to query them if necessary.

\subsection{Creating an External Data Model}

The external data with address data, archive data, land cover data, party data, land use data, physical utility network data, taxation data and valuation data is outside the scope of the LADM. However, LADM provides stereotype classes for these external datasets, which indicate what dataset elements LADM expects from these external sources, if available. Figure 1 shows an overview of external classes concerning the LADM basic classes.

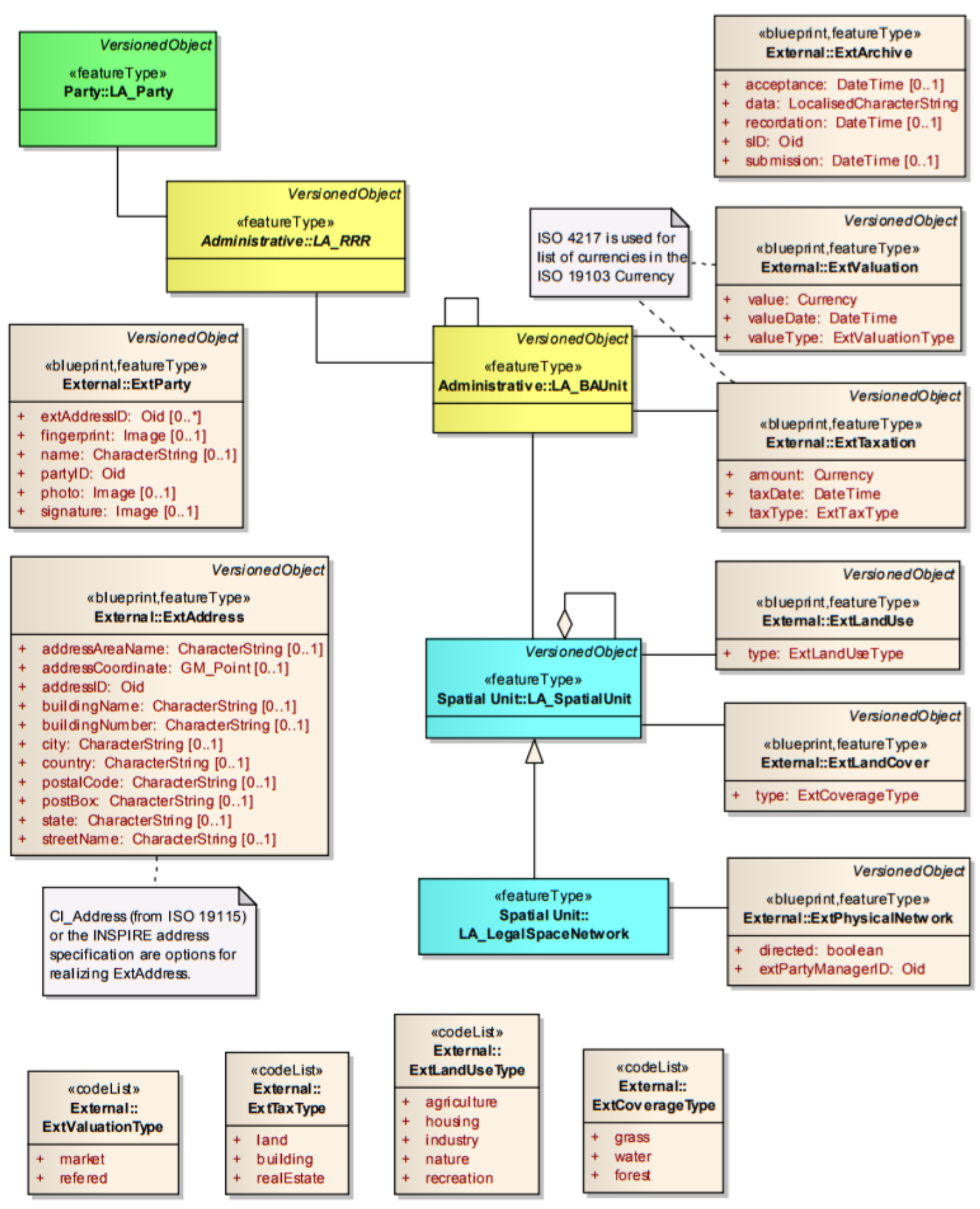

Figure 1: External LADM Classes (Lemmen et al.,2011) 
The name of the external data model representing the operations carried out for the real estate properties of the treasury is designed as "TREM_TreasurysRealEstateExternalModel" (Figure 2). In this section, models for management, acquisition and disposal are presented and explained separately. The classes of these operations will be associated with LADM in the next section.

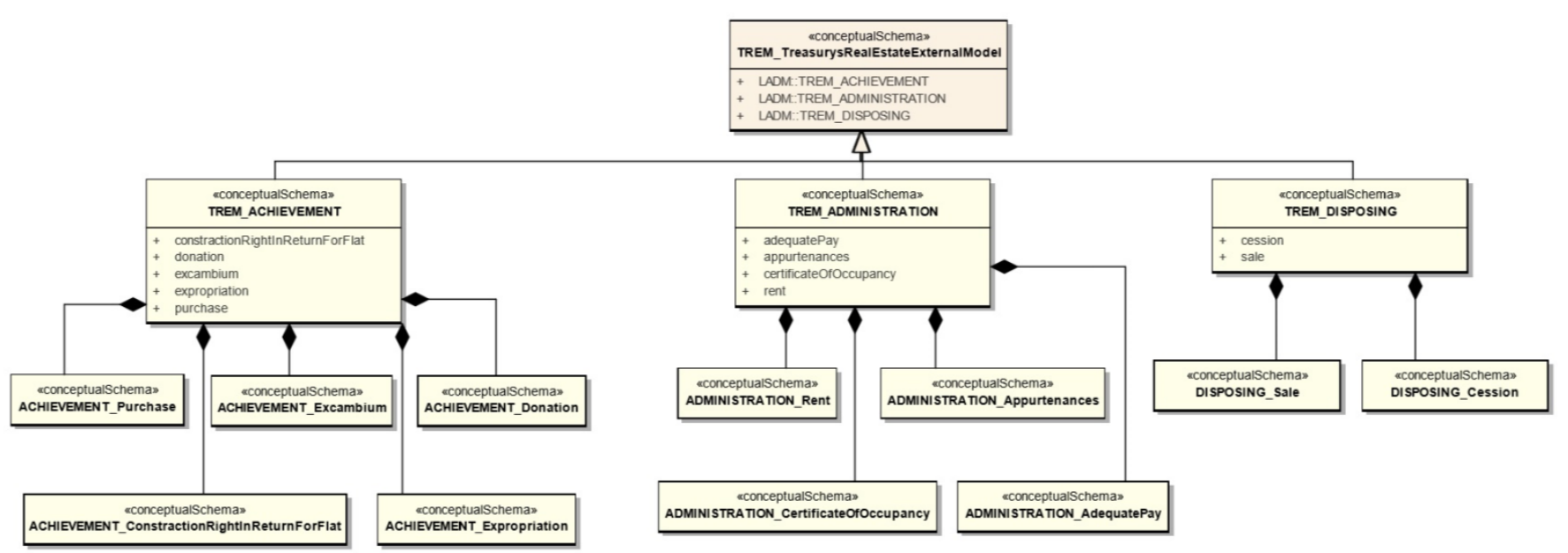

Figure 2: Treasury Real Estate General External Data Model

\subsection{External Data Model for Achievement Process}

In this section, a class named TREM_Achievement is defined as an external data source, which represents the acquisitions of the treasury. The following classes are defined in this class and explained in the subsections together with UML schemas.

- ACHIEVEMENT_Donation for donations to the treasury,

- ACHIEVEMENT_Purchase classes are defined for transactions related to real estates purchased in the public interest on behalf of the treasury,

- ACHIEVEMENT_Expropriation sub-class is to the preparation of zoning plans for transactions related to expropriated areas to be used for studies,

- ACHIEVEMENT_Excambium for trading transactions where one party is a treasure,

- ACHIEVEMENT_ConstructionRightInReturnforFlat for construction operations in exchange for land or floors owned by the treasury.

Donation is the transfer of ownership property from one of the owners to another person or institution. The donation process is without waiting for a payment in return. For the donations made to the Treasury, the transaction steps specified in the National Property Provincial Units Transaction Directive are applied. Figure 3 shows the donation UML schema for the transactions of the donation. 


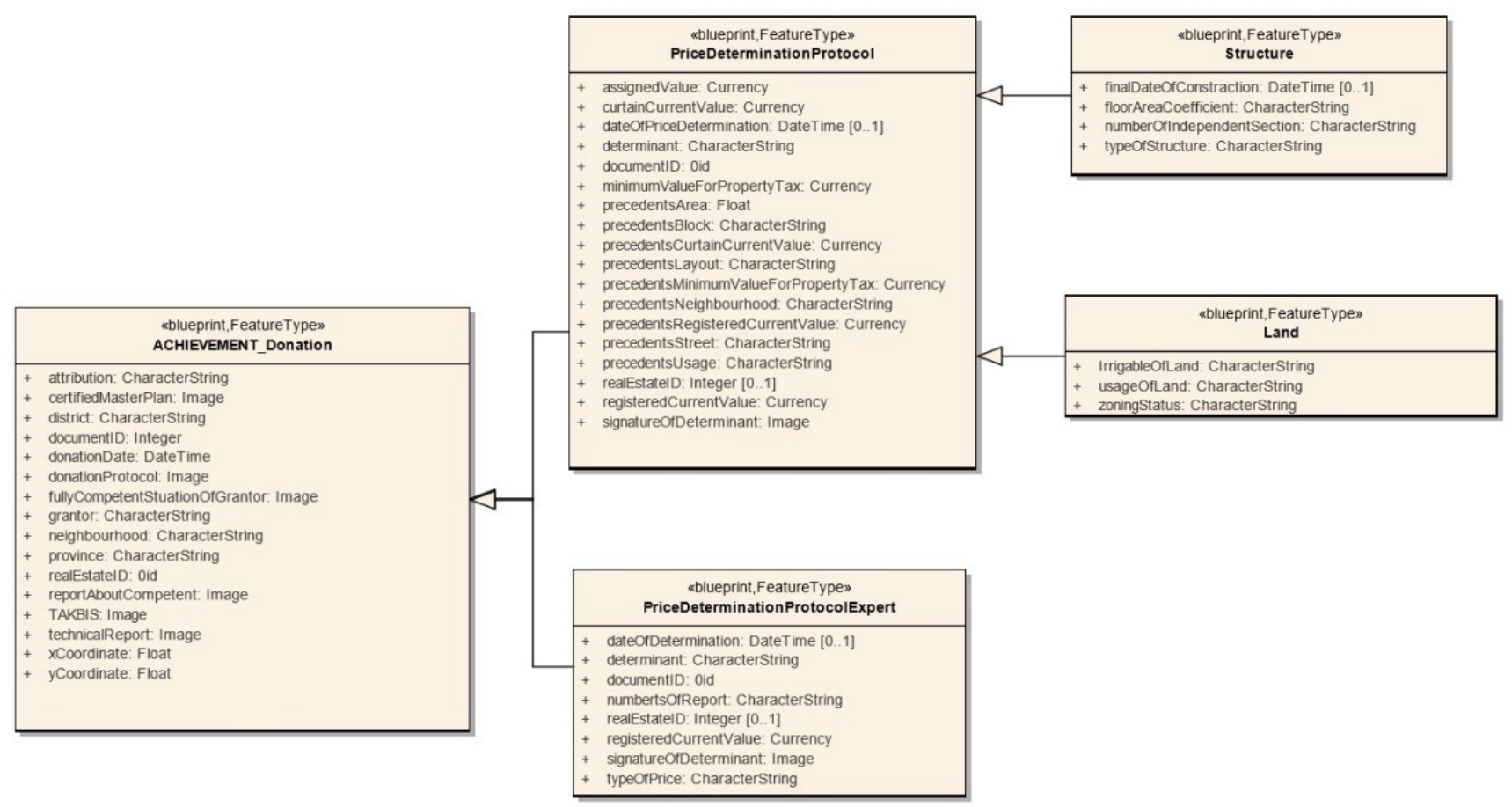

Figure 3: Achievement_Donation UML external data model

The state can acquire the real estates it needs through purchase. The procurement of the state is subject to different procedures from legal and natural persons. Since the ownership of the real estate will be transferred to the Treasury, permission is obtained from the Ministry of Finance before all transactions are carried out. Following the permission obtained, the purchase procedure is carried out by following the steps of the purchase procedure of the National Property Provincial Units Transaction Directive. The value of the real estate is determined for each purchase. For this, either the proper administration or expert reports shall be taken as the basis. This selection is divided into two as the required attribute data differs depending on whether the real estate planning to be purchased land, land or building. This distinction will affect the price of the real estate and therefore, the Treasury (Figure 4). 


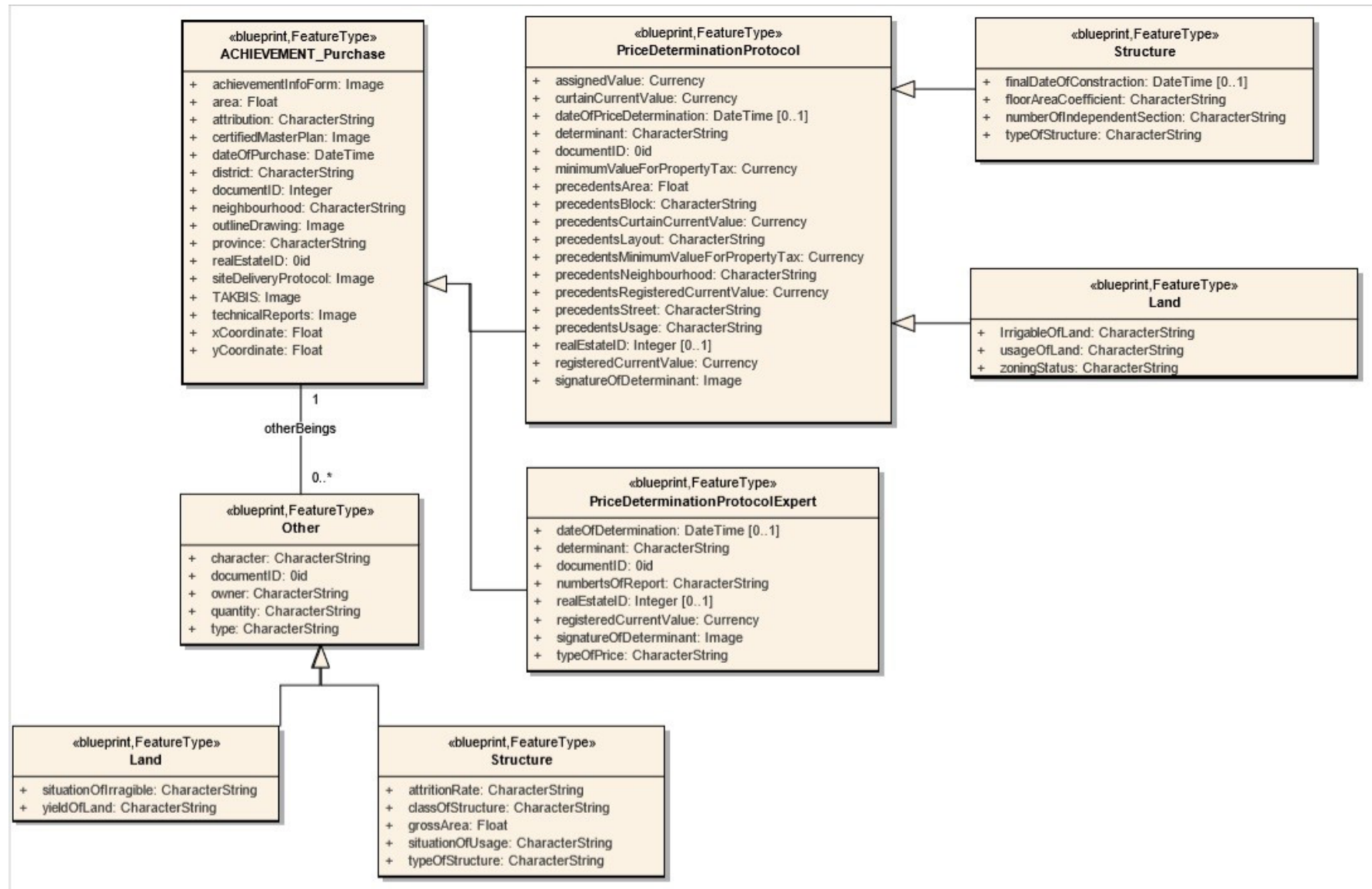

Figure 4: Achievement_Purchase UML external model

Figure 5 shows the expropriation UML schema for the transactions of the process of the land registry. "Expropriation; It is the transfer of real estate, resources and easement rights that are in the ownership of real and private legal entities to the public property regardless of the consent of the owner, provided that the real provision is paid in advance in cases where the public interest requires." The first condition in the expropriation process is that the expropriation process should be done with the benefit of the society. As in every acquisition process, permission is first obtained from the Ministry in the expropriation process. Following the permission, the National Real Estate Provincial Units Transaction Directive Expropriation is carried out by following the steps of expropriation. By the scale plan attribute, here is meant the scale plan showing the boundary, surface area and type of the real estate subject to expropriation by the administration. With the approved zoning plan attribute, an approved zoning status document from the municipality or a cadastral or zoning parcel is marked on it, and an approved zoning plan sample is defined.

Excambium is the condition of replacing the ownership of a property or right with the property of another person. Permission is obtained from the Ministry before proceeding. Following the permission, the procedures are started. Process steps to be followed The UML diagram designed according to the National Real Estate Provincial Units Transaction Directive is given in figure 6. Here, if the acquisition with the Council Decision attribute is acquired, the examination of how, what, how, where and from which cadastral maps are made, the registration of the zoning plans with the cadastral maps, the cadastral roads, parks, squares and similar places and zoning practices acquired through the settlement. This issue is marked by marking the most recent zoning plots and their status and location, by marking the areas that were left as a result or the places covered by the regulatory partnership share in the latest approved zoning plans; The technical report is prepared by interpreting the legislation and judicial decisions, and all information and documents and committee decisions related to these issues are meant. 


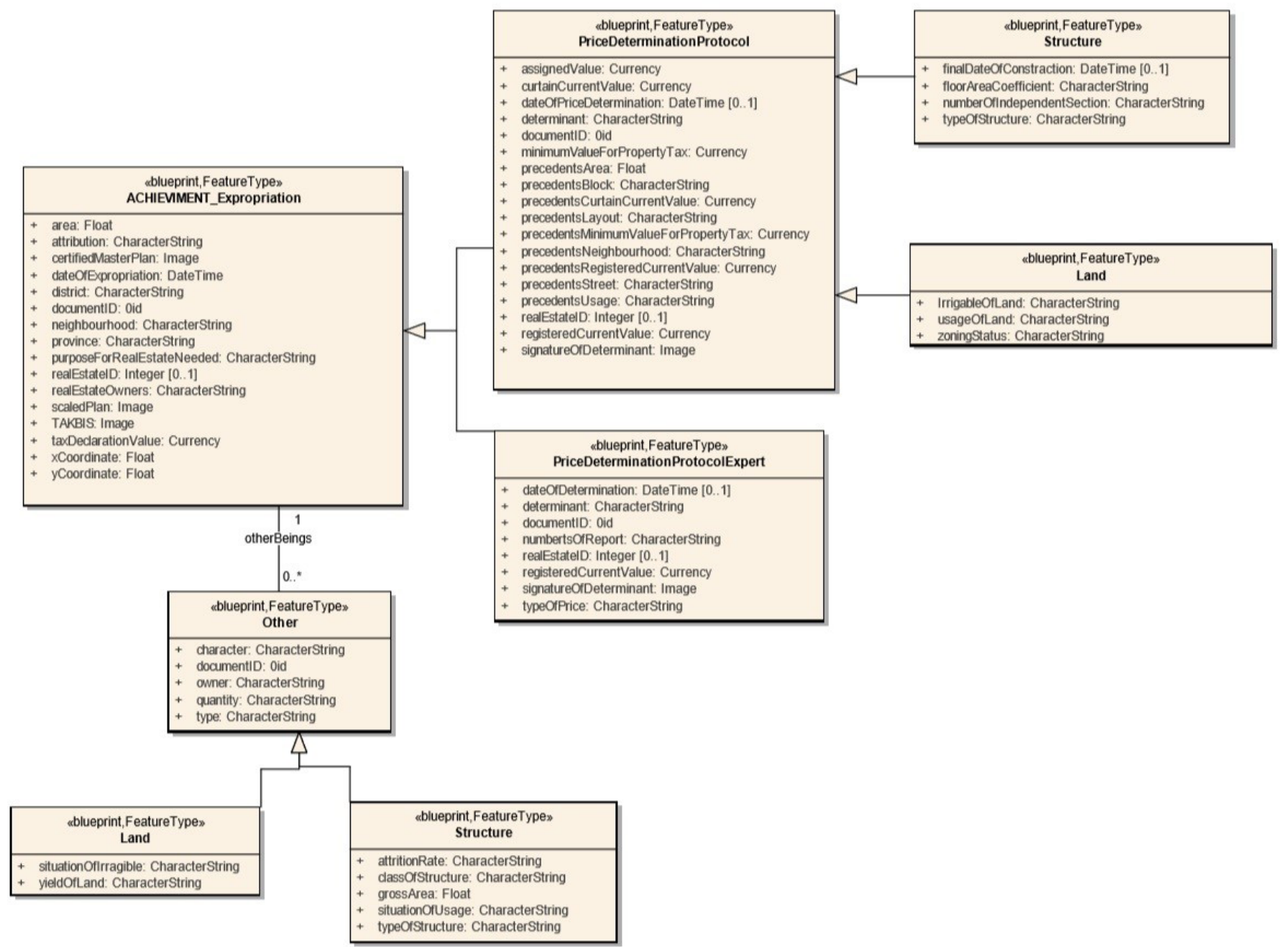

Figure 5: Achievement_Expropriation UML external model

The construction contract for the floor is a condition registered on the land of one party contractor and the landowner of the other party. Thus, it is an agreement for the construction of integrated building by building independent sections against ownership of individual shares in the land. With this agreement, landowner made it to transfers of some part pf the ownership rights to the contractor (or a third party). The excellence of the remaining shares remains with the landowner. On the other hand, the Contractor undertakes to make independent sections in exchange for the shares of the land to be transferred to him, and he owes the transfer to those who hit the landowner. Since the Treasury does not want to deal with the construction-related transactions, it assigns some of the independent sections to be made to the land belonging to the Treasury to the contractor. In the construction method for the land, the state gives the land to the contractor. For this reason, condominium section is given to the state in exchange for land. Treasury will acquire real estate by these methods (Figure 7.).

The construction contract for the floor is a type of construction contract not regulated by law. The land share construction contract is the construction of one party on land owned by the other party, and in return, the landowner party transfers the determined land shares to the other party's property. Construction for the land is to give another land to the other party in return for construction. All these transactions are carried out with a contract. One of the parties is the Treasury and the other is a public institution or private owner. 


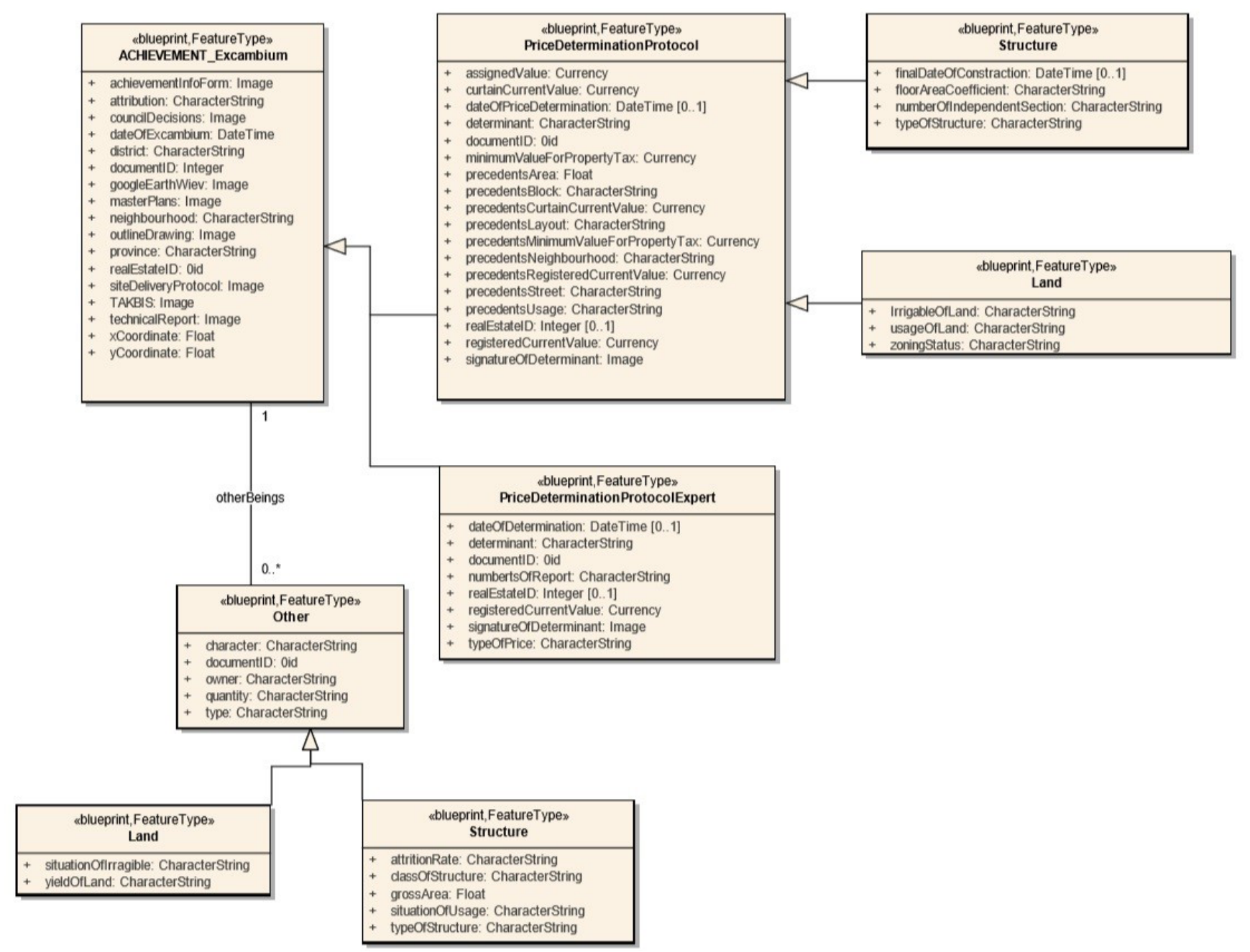

Figure 6: Achievement_Excambium UML external model

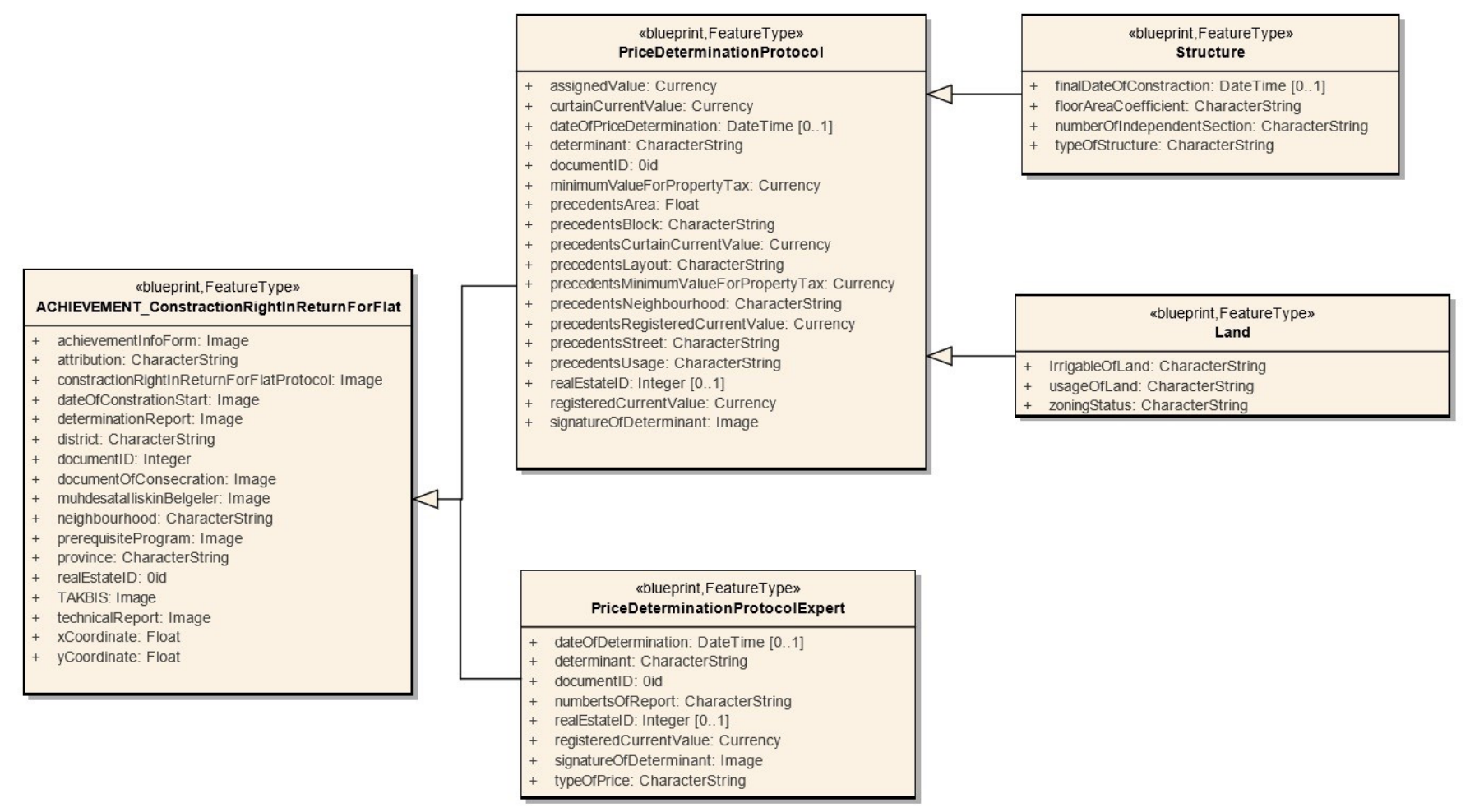

Figure 7: Achievement_ConstructionRightInReturnforFlat UML external model 


\subsection{External Data Model for Administration Process}

In this section, a class named TREM_Administration is defined as an external data source, which represents the management operations from the transactions on the real estate properties of the treasury. The designed models realized within this class are given in the following items. Then, it is explained together with database schemas.

- ADMINISTRATION_Easement procedures for real or legal persons to establish easement rights on the real estate property,

- ADMINISTRATION_CertificateOfOccupancy required for real or legal persons to obtain permission to use on real estate property,

- ADMINISTRATION_AdequatePay for transactions applied in cases where real estate properties are found to be occupied

- ADMINISTRATION_Rent classes are available for transactions related to the leasing of real estates by real and legal persons.

The right of easement is a process that gives the right holder the right to use, benefit from or use both of a real estate. On the other hand, it may also be treated as a kind that restricts the owner's right to property and prevents him from exercising his rights arising from the property. An easement agreement is concluded between the person/institution requesting easement and the state institution. Here, as in the usage permit diagram, one of the two authorized groups will be preferred in order to determine the price of the real estate and the real estate that has been eased will be guided in the determination of the price (Figure 8.).

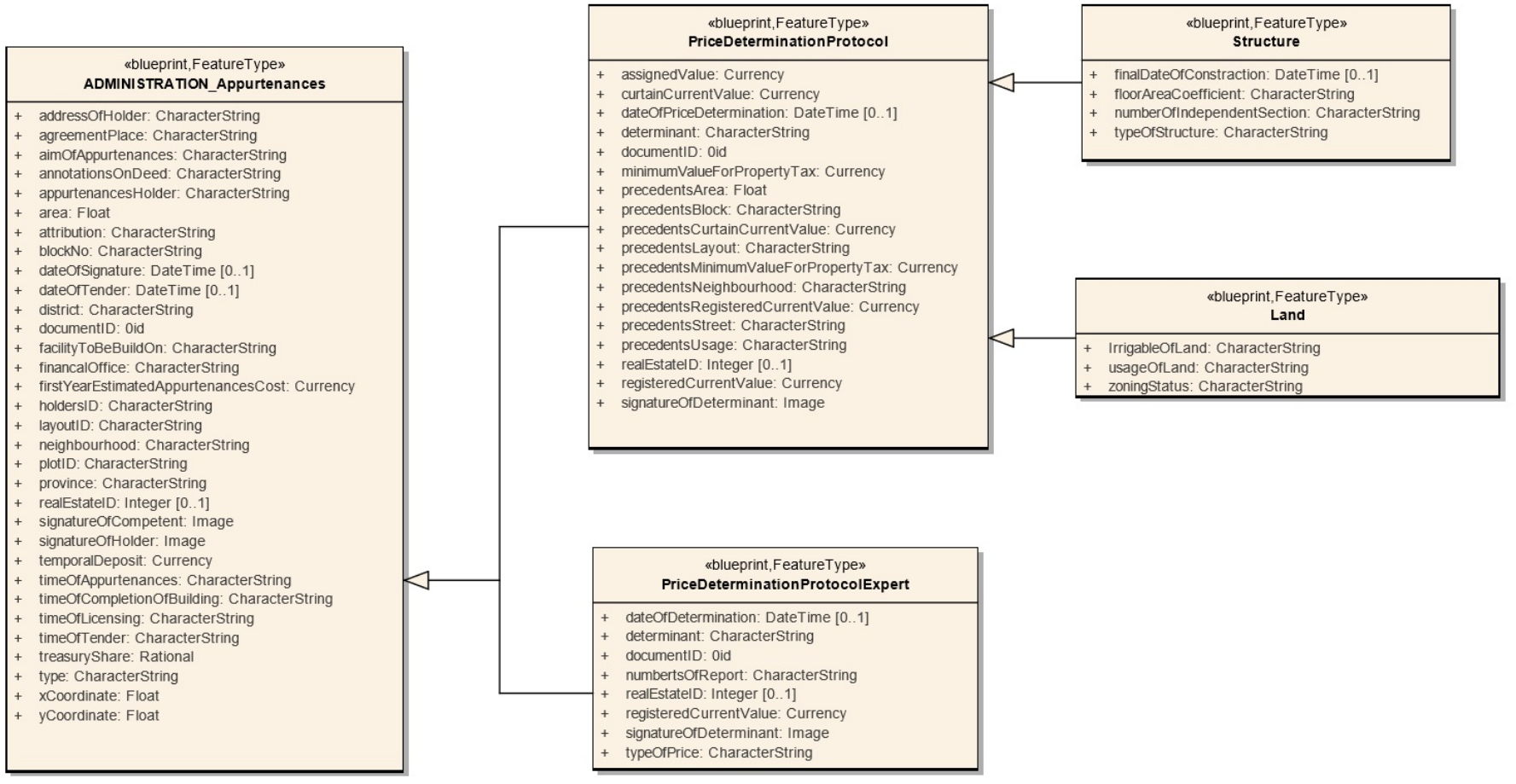

Figure 8: Administration_Easement UML external model 
It is possible to transfer the right of use of the real estate belonging to the state to third parties for a specified period. According to the relevant laws, GDNRE may grant this use permission in favour of individuals for specific periods. In this case, the official protocol is executed between the person/institution requesting permission and the institution that meets the request. Under this protocol, qualification information is represented in the database (Figure 9). In this context, the registered current occupancy value is determined by the administration. Also, expert according to the structure in the region. This selection is divided into two, as the required attribute data differs depending on whether the real estate property to be used for permission is a land, land or building. This distinction will affect the price of the real estate and therefore, the price of the permit to use it.

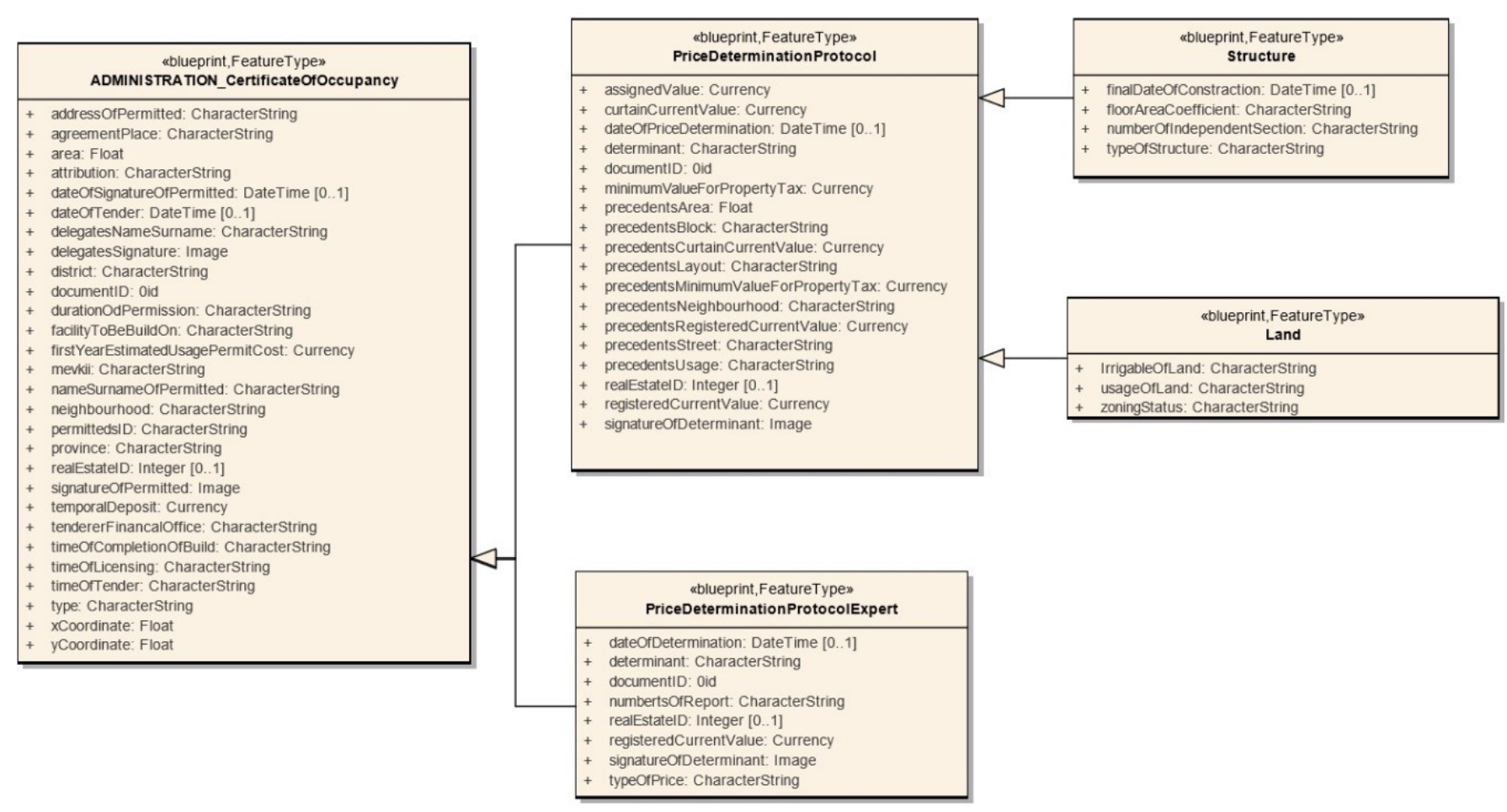

Figure 9: Administration_CertificateOfOccupancy UML external model

Property can be used on the real estate property belonging to the treasury by occupation without Administration permission, rent or easement. When such cases are identified, a notice of redundant occupation shall be sent, followed by a court receivable. The Administration_AdequatePay UML class diagram designed in this context is given in Figure 10.

Although adequate pay is referred to as the Treasury's management process, it is a disciplinary process. This situation has become an ordinary transaction due to the common occupation of Treasury real estates and has become a deterrent. The fair pay price cannot be less than $5 \%$ of the real estate tax base value. As can be seen from here, the cost of adequate pay is planned to be higher than the rent, which is an effort to discourage the occupation and to use proper methods such as leasing. However, there is a problem in the stage of receiving the penalty from the occupier. Here, the instalment of the debt or the provision of discounts in cash disrupts deterrence and paves the way for occupations. 


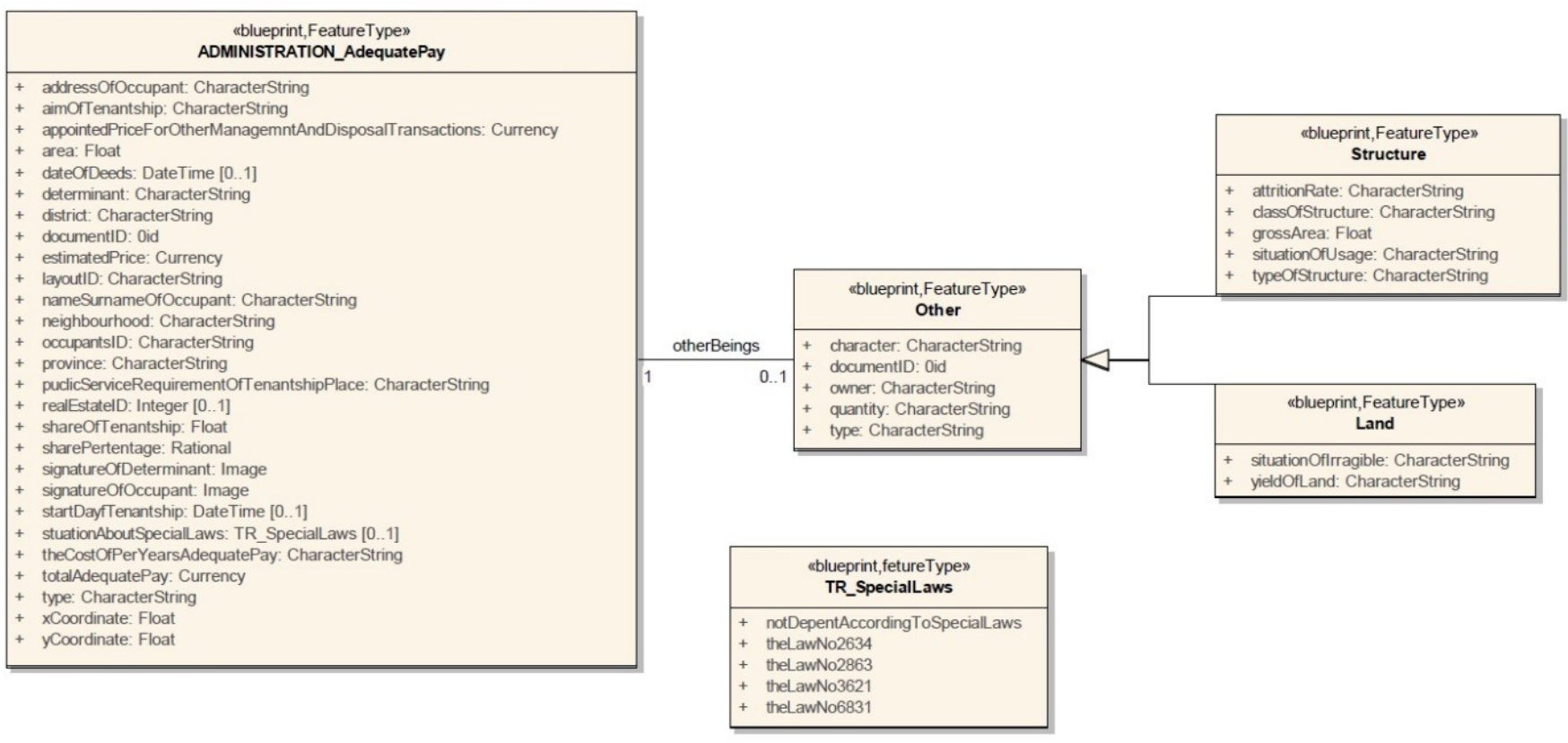

Figure 10: Administration_AdequatePay UML external model

Renting of a house, a vehicle, a property, in other words, movable/real estate property for a price, is given by the owner to another person for a period of time. In cases where the owner of the property is the Treasury from these parties, leasing can be done against the protocol. In calculating the rental price, $4 \%$ of the fair value of the real estate is taken as a basis. TR_TypeOfTender selection table has been prepared in order to make the selection which tender type has been decided during the determination of the tenant (Figure 11.).

\begin{tabular}{|c|c|}
\hline $\begin{array}{l}\text { "blueprint,FeatureType» } \\
\text { ADMINISTRATION_Rent }\end{array}$ & $\begin{array}{l}\text { «blueprint,FeatureType» } \\
\text { EstimatedHirePurchase }\end{array}$ \\
\hline $\begin{array}{l}+ \text { addressOfHirer: CharacterString } \\
+ \text { agreementPlace: CharacterString } \\
+ \text { aimOfHiring: CharacterString } \\
+ \text { area: Float } \\
+ \text { + attribution: CharacterString } \\
+ \text { blockNo: CharacterString } \\
+ \text { chiefOfDisbursement: CharacterString } \\
+ \text { dateOfHirersSignature: DateTime }[0 . .1] \\
+ \text { dateOfTender: DateTime } \\
+ \text { district: CharacterString } \\
+ \text { documentID: Oid } \\
+ \text { financalOffice: CharacterString } \\
+ \text { firstYearEstimatedHirePurchase: Currency } \\
+ \text { hirer: CharacterString }\end{array}$ & $\begin{array}{l}\text { + } \text { averageDailySales: Currency } \\
+ \text { competent: CharacterString } \\
+ \text { documentID: Oid } \\
\text { + } \text { energyCostCoveredByUnit: Boolen } \\
+ \text { estimatedSalePrice: Currency } \\
+\quad \text { metarialsCoveredByUnit: Boolen } \\
+ \text { numberOfDaysOpenInOneYear: Integer [0..1] } \\
\text { + } \text { qualityOfGoodsToBeSold: CharacterString } \\
+ \text { realEstateDeditacedUnit: CharacterString } \\
+\quad \text { realEstatelD: Integer [0..1] } \\
+\quad \text { responsibleAuthority: CharacterString } \\
+ \text { saleExtentPersonnel: Boolen } \\
+\quad \text { signatureOfCompetent: Image }\end{array}$ \\
\hline $\begin{array}{l}+ \text { layoutID: CharacterString } \\
+ \text { neighbourhood: CharacterString }\end{array}$ & $\begin{array}{l}\text { "CodeList" } \\
\text { TR_TypeOfTender }\end{array}$ \\
\hline $\begin{array}{l}\text { + } \text { plotID: CharacterString } \\
+\quad \text { province: CharacterString } \\
+\quad \text { realEstatelD: Integer }[0 . .1] \\
+\quad \text { signatureOfHirer: Image } \\
+\quad \text { temporalDeposit: Currency } \\
+\quad \text { timeOfTender: CharacterString } \\
+\quad \text { treasuryShare: Rational } \\
+\quad \text { type: CharacterString } \\
+\quad \text { typeOfTender: TR_TypeOfTender }[0 . .1] \\
+\quad \text { xCoordinate: Float } \\
+\quad \text { yCoordinate: Float }\end{array}$ & $\begin{array}{ll}+ & \text { bargain } \\
+ & \text { betweenDefiniteBuyers } \\
+ & \text { directRequirement } \\
+ & \text { openTender }\end{array}$ \\
\hline
\end{tabular}

Figure 11: Administration_Rent UML external model 


\subsection{External Data Model for Disposing Process}

In this section, a class named TREM_Disposing is defined as an external data source, which represents the disposal of the treasury.

- DISPOSING_Cession for the transactions related to the transferor transfer of the real estate property owned by the treasury to the ownership of real or legal persons.

- DISPOSING_Sale classes for the sale of a property owned by the treasury are available within this class.

The laws concerning the transfer of goods without cash can be grouped into two groups. The first group includes the transfers to some statesmen. In the second group, some laws provide free transfer for commercial purposes such as encouraging agricultural and industrial development, and social purposes such as assisting people suffering from natural disasters. Free transfer and abandonment operations can be carried out within the framework of a protocol which is represented in the database (Figure 12). The point to be considered in this model is the law within which the transfer process takes place. Because the constraints and requirements of each law are different, the attribute to be added to the UML diagram is also different.

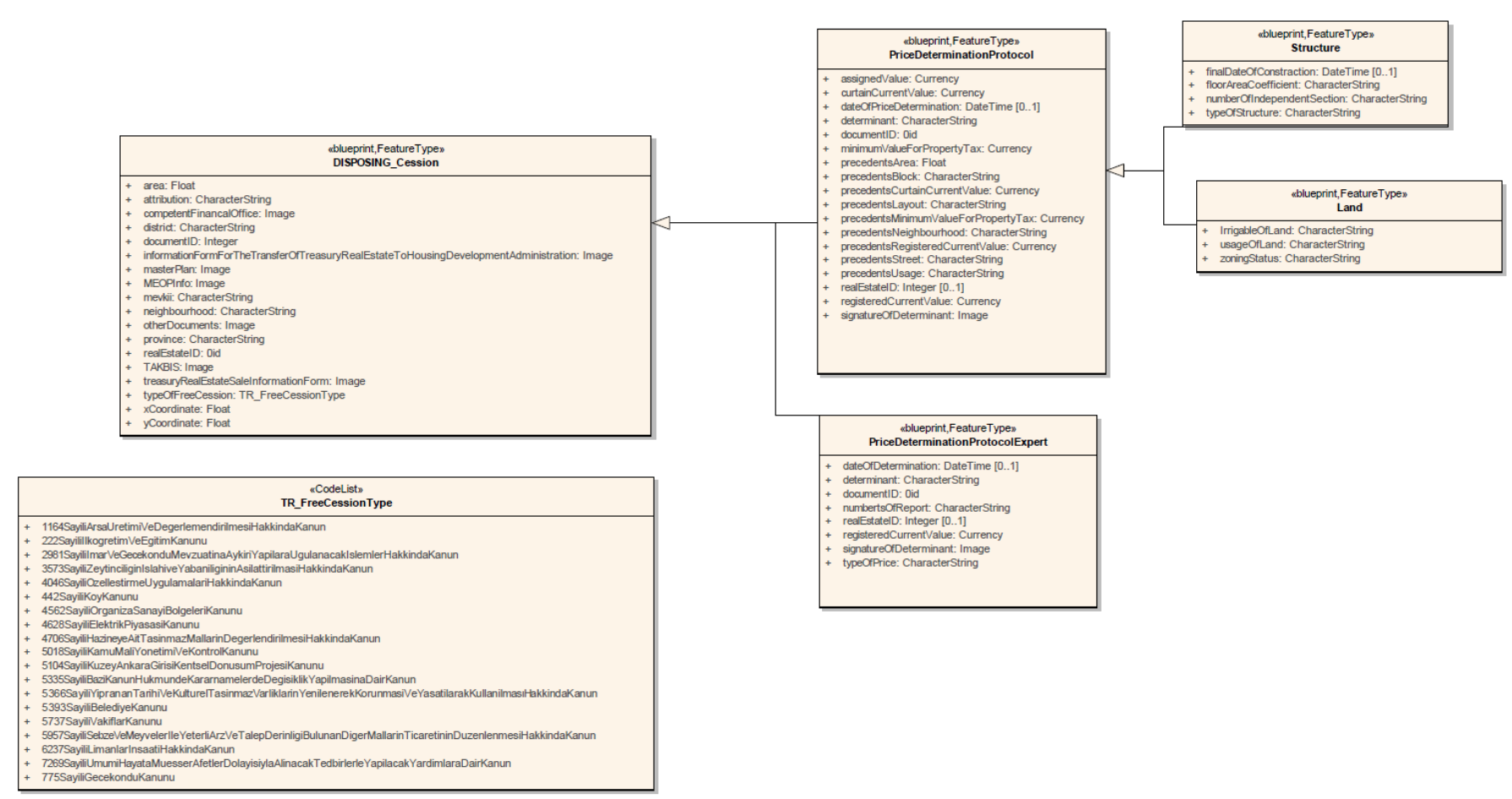

Figure 12: Disposing_Cession UML external model

The sales transactions realized by the treasury are divided into three as sales, direct sales and sales based on the principal value of the fee. The sale of the treasury is carried out within the framework of a specific protocol. The database schema designed in this context is shown in Figure 13. Sales can be made in advance or by instalments. Here, as in the rental process, the tendering method may vary. A code list of TR_TypeOfTender has been created to select the type of tender awarded. The TR_SaleType code list is also created to select the type of sales transaction (Figure 13). 


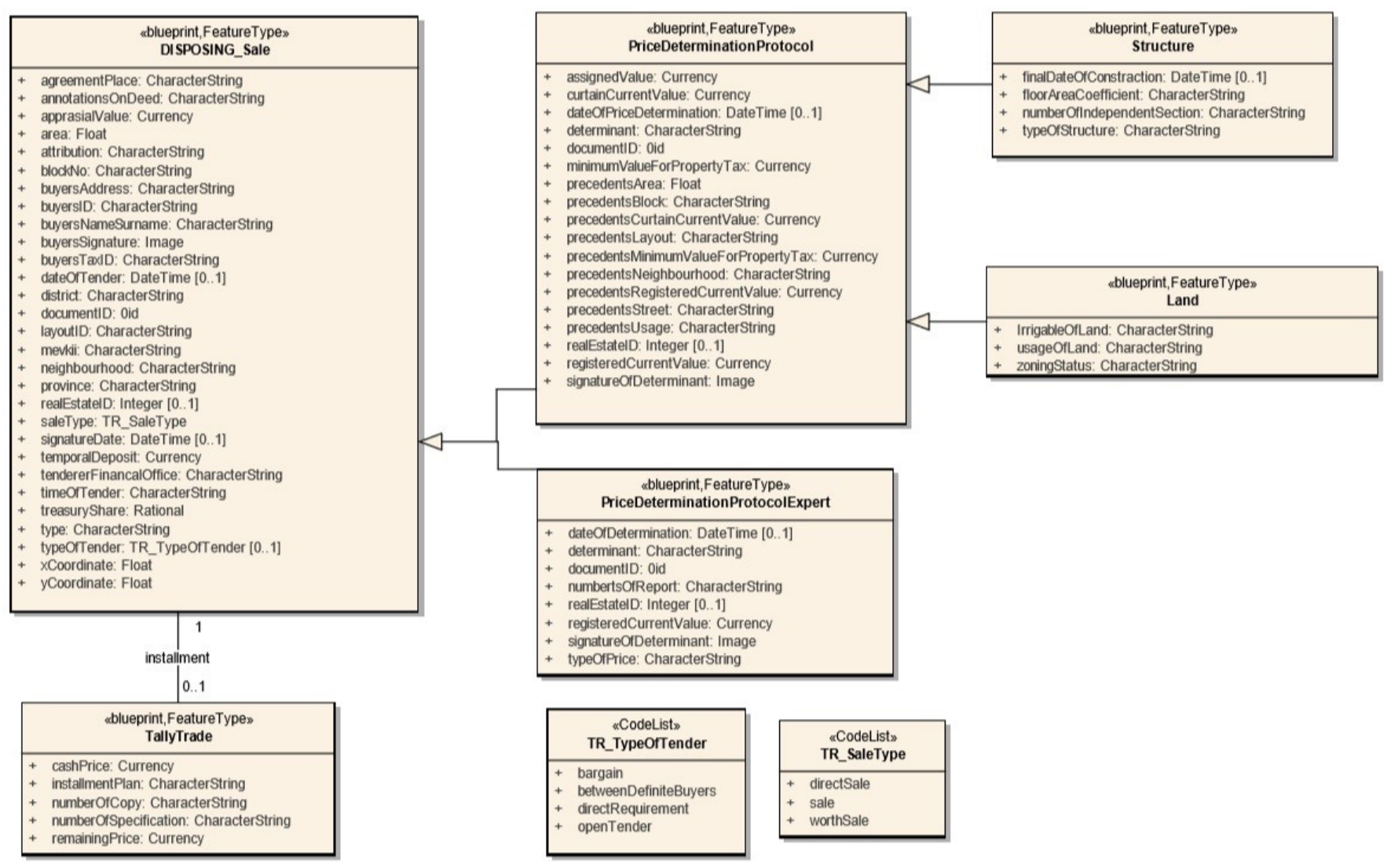

Figure 13: Disposing_Sale UML external model

\subsection{Associating the External Data Model with LADM}

TREM_TresuaryExternalDataModel was designed to represent the transactions carried out on treasury properties. The TREM_Achievement, TREM_Administration and TREM_Disposing UML classes are defined according to the content of the information and documents in this class (Figure 2.). -_TerasuryRealEstateExternalModel is related to LADM's LA _ Party, LA_RRR, LA_SpatialUnit, LA_BAUnit classes in terms of information and documentation (Figure 14.).

Since the ownership of the real estates will change in TREM_Achievement transactions, there must be at least two parties during the transaction, one of which is the Treasury. All transactions are linked to the LA_Party class and the LA_BAUnit classes since it is a handover operation, and there will be changes in the administrative data of the property. Depending on the real estate, it is associated with LADM, while the multiple connections "0..* ile is established with the LA_Level and LA_LegalSpaceBuildingUnit classes, the subclass of the LA_SpatialUnit class.

In TREM_Adminitration transactions, the LA_Party class is linked to the type of management to be assigned on the real estate property, one of which is always the Treasury. Due to the adequate pay, easement and usage permission classes in the management operations, bağlant $0 . . *$ "multiple connections have been established with the LA_Responsibility and LA_Restriction subclasses of AITM's LA_RRR class. Depending on the type of land (land, land, building section, etc.), the LA_SpatialUnit class is linked. 


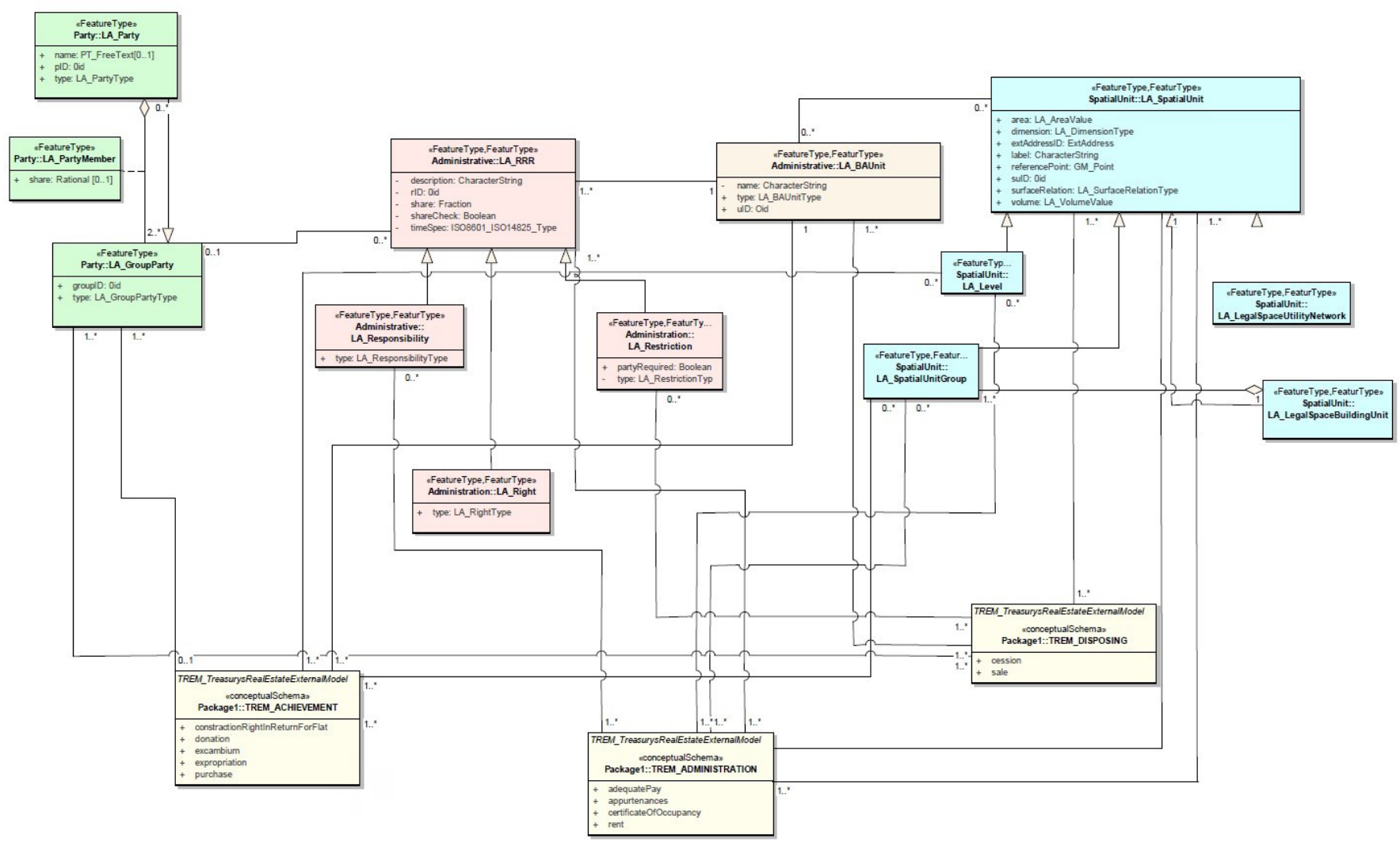

Figure 14: The UML external model associated with the LADM data model

In TREM_Disposing operations, there are at least two parties during the process, one of which is the Treasury. For this reason, "1. **" multiple relationships are established with LA_Party class. Since the ownership of the real estate will change hands, the administrative data will be changed, and the registration process should be performed. There may be at least one real estate or more than one real estate. For this reason, "1. **" multiple relationships are established with LA_BAUnit class. In the case of handover transactions from the disposal process, some annotations and restrictions may be imposed on the transferred real estate property (e.g. transfer operations for organized industrial zones or training areas). For this reason, "0.." multiple relationships were established with LA_Restriction subclass of LA_RRR class.

\section{Discussions}

The aims planned to be achieved with the designed model, and the deficiencies of the existing system are listed below.

1. Protocols are identified about data storage and management in GDNRE. There is no standard for storing data, as the organization specifies a separate storage protocol for each transaction. Due to the external data model developed through the LADM infrastructure, the management of external data will be standardised.

2. During the transactions on treasury real estates, much unnecessary information is requested in terms of ownership information within the scope of the present directives, and all of them require more storage space than necessary to be stored. It causes slowness during the process flow. While analysing the information and documents, these unnecessary data's were extracted, and standardization was made in the direction 
of the remaining areas. As a result of this study, only the necessary information will be queried using the external data model. The designed external data model will reduce time loss during the inspection.

3. There is no ordinary or extraordinary time-out in cases that protect property rights to be opened for real estates under the administration of the Treasury. Inadequate pay lawsuits, there are problems such as loss of documents, fraying or lack of accessibility. With the created external data model, the information will be stored in the computer environment after physical archives. As this will eliminate the loss of documents, there will be legal guidance in cases where there is no time-out in the proceedings.

4. Like a certificate of occupancy, easement and rent transactions such as lease are finite term transactions. Due to the simple inquiries to be made in the information system established by the implementation of the external data model, the expiry dates of the finite-term transactions can be determined. All these situations will save time and paperwork.

5. An External data model there is a lack of both in the context LADM in the context of e-government projects ongoing in Turkey. In this context, the study is designed to eliminate this deficiency.

\section{Conclusions and Recommendations}

Within the scope of this study, an external data model compatible with LADM has been designed in order to manage the transactions carried out by the GDNRE on Treasury real estate over a geographical database. In case the external data model is adopted and implemented by the responsible institutions, the processing times will be shortened, the access to the documents will be provided faster in legal and administrative situations, and the workflow will be accelerated thus accelerating the workflow.

In order to achieve the primary purpose of this study, the general structure of LADM was examined, which is a literature review. Besides the general LADM and external classes, it has been mentioned in some studies in Turkey. At the same time, this research showed that the LADM found what extent in Turkey.

In this study, primarily related databases where data is saved and property rights in Turkey were examined based on the positional data record. As a result of this review, it was found that none of the employee databases included a record of transactions in Treasury real estate. In this context, international studies on geographic data standards have been examined in order to solve this problem. Hence the database will be used in the standardization process for Turkey has been discussed with the UML modelling language. LADM, which proposes a standard model for a sustainable land administration, is applicable in our country's land administration.

The transactions carried out on the basic classes of LADM, and the Treasury real estates (carried out by GDNRE) were examined in detail and the connections of the external model to be developed with the base classes were determined. Information, documents and contracts used for Treasury real estate transactions, which are the main processing steps of the external class, are reviewed in this section. Then, the described processes are modelled following the obtained information and documents, and the obtained external model is associated with the primary classes.

Results obtained from the application of the external data model have been performed. Also, within the scope of this study, this is given below. Also, considering the five items given in the discussion section, the actions taken against the deficiencies are given below in general.

1. Protocols on data storage and management within the National Real Estate Agency have been determined. With this study, the external data model developed with LADM infrastructure enabled the management of external data to reach international standards. 
2. During the transactions to be carried out on treasury real estate, much unnecessary information is requested in terms of ownership information within the scope of the present directive and causes more storage space to be allocated for all of them.

3. In this study, with the created external data model, the information will be stored in the computer environment after physical archives.

4. Permission to use, easement, transactions such as lease are finite term transactions. With the help of simple inquiries in the information system established by the implementation of the external data model, the end dates of the finite time transactions can be determined. If deemed necessary, the extension of the agreement period may be made on the information system. All these situations create solutions to eliminate the problems of tedious, time consuming, and error-prone task.

In order to make the data model developed within this study more efficient, the following suggestions are presented.

1. The data model needs to be implemented, and the deficiencies and errors that occur at this stage need to be identified.

2. The active user of the external data model system proposed in this thesis will be the GDNRE. However, some requirements must be met for the designed external model to function as functional and sustainable. All institutions and individuals involved in the implementation of external data management required by this model are required to carry out the necessary studies and bring their physical infrastructure to the appropriate structure. In particular, the absence of one of the external information and document providers will cause the proposed model to function.

3. In the current usage, the acquisition and control of the annotations, title deeds, address and identity information on the real estate property after the approval of the Ministry by National Real Estate is performed through TAKBIS using the web service. Furthermore, these services should be integrated into the designed external data model to stream data from web services such as TAKBIS.

\section{AUTHOR'S CONTRIBUTIONS}

All authors contributed equally.

\section{REFERENCES}

Alkan, M. and Polat, Z. (2016). "Determining Spatio-Temporal Cadastral Data Requirement for Infrastructure of Ladm for Turkey”. XXIII ISPRS Congress, $12-19$ July 2016, Prague, Czech Republic.

Alkan, M. and Polat, Z. (2017-a). "Design and development of LADM-based infrastructure for Turkey", Survey Review, 49: 370-385.

Alkan, M. and Polat, Z. (2017-b). "Design and Determine the Spatio-Temporal Cadastral Data Infrastructure for LADM", FIG Working Week 2017, May 29- June 2, Finland.

Alkan, M. and Sürmeneli, H.G., (2017). No Access Development of an advertisement tax system based on a geographic information system, Proceedings of the Institution of Civil Engineers - Municipal Engineer, DOI: 10.1680/ jmuen.16.00028. 
Cete, M. (2008). Türkiye için bir arazi idare sistemi yaklaşımı, Doktora Tezi, KTÜ Fen Bilimleri Enstitüsü, Trabzon.

Cete, M. and İnan, H.i. (2013). "Kadastroda Modern Eğilimler ve Türkiye Kadastrosu”, 14. Türkiye Harita Bilimsel ve Teknik Kurultayı, 14-17 Mayıs, Ankara.

Coruhlu, Y.E. and Yildiz, O. 2017. Geographical data model for cultural immovable properties, Survey Review, 50 (363), 487-500.

Coruhlu, Y.E., Inan H.I., Yilmaz H., and Demir O. 2015. Geographic data model of foundation immovable. Sigma journal of engineering and natural sciences-sigma Muhendislik ve Fen Bilimleri Dergisi, 33, 539-559.

Çağdaş, V. Kara, A. Oosterom, P.J.M. Lemmen, C. Işıkdağ, Ü. Kathmann, R. and Stubkjær, E., (2016). «An Initial Design Of ISO 19152: 2012 LADM Based Valuation And Taxation Data Model», ISPRS Annals of Photogrammetry, Remote Sensing \& Spatial Information Sciences, 4: 145-154.

Dale, P. F. and McLaughlin, J. D., 1988. Land Information Management, Oxford University Press, New York, ISBN: 0-19-858404-0, $266 \mathrm{~s}$.

Dale, P.F. and McLaughlin, J. D., 1999. Land Administration, Oxford University Press, New York, ISBN: 0-19-823390-6, 169 pages.

Döner, F., (2010). Türk Kadastro Sistemi İçin Üç Boyutlu Yaklaşım, Doktora Tezi, Karadeniz Teknik Üniversitesi Fen Bilimleri Enstitüsü Trabzon.

İnan, H. (2010). Arazi İdare Sisteminin Tarım Bileşeni Olarak Konumsal Veri Modeli Geliştirilmesi, Doktora Tezi, KTÜ Fen Bilimleri Enstitüsü, Trabzon.

İnan, H.i. and Yomralıoğlu, T., (2011). «Arazi İdaresi İçin Konumsal Modelleme», HKMO Jeodezi, Jeoinformasyon ve Arazi Yönetimi Dergisi, 1: 21-29. https://www.hkmo.org.tr/resimler/ekler/a98bcc442b9a8e2_ek.pdf

Kaufmann, J. and Steudler, D. (1998). Cadastre 2014, A vision for a future cadastral system, FIG.

Lemmen, C. Oosterom, P.J.M. Zevenbergen, J. Quak, W. and Molen, P., (2003). “Further progress in the development of a core cadastral domain model", FIG Working Week, France.

Lemmen, C. and Oosterom, P.J.M. (2003). Towards a Core Cadastral Domain Model, GIM International

Oosterom, P.J.M. Lemmen, C. Ingvarsson, T. Molen, P. Ploeger, H. Quak, W. Stoter, J. and Zevenbergen, J., (2006-b). "The core cadastral domain model", Computers, Environment and Urban Systems, 30: 627-660.

Oosterom, P.J.M., Lemmen, C. Ingvarsson, T. Molen, P. Ploeger, H. Quak, W. Stoter, J. and Zevenbergen, J. (2006-a). "The core cadastral domain model", Computers, Environment and Urban Systems, 30: 627-660.

Özçelik, A. (2013). Özel Tarım Ürünü Arazilerine Yönelik Konumsal Veri Modeli Geliştirilmesi: Çay Tarımı Örneği Doktora Tezi, Fen Bilimleri Enstitüsü, Karadeniz Teknik Üniversitesi, Trabzon.

Polat, Z. A. (2018), Arazi Yönetiminde Tapu ve Kadastro İşlemlerine Yönelik Harici Veri Modeli Tasarımı ve Uygulaması, Doktora Tezi, Yıldız Teknik Üniversitesi Fen Bilimleri Enstitüsü, İstanbul.

Sevük, F. and Beceren, M. 2017. Milli Emlak ve Hazine Taşınmazlarının Yönetimi, Yerel Mevzuat Eğitim ve Yayıncılık. Steudler, D. (2003). Developing evaluation and performance indicators for SDIs. Williamson, I. Rajabifard, A. \& MF Feeney (2003)(Eds.): Developing Spatial Data Infrastructures: From concept to reality. Taylor \& Francis, London, 235-246.

Taş Arslan, E., and Çağdaş, V. (2018) Türkiye'de Taşınmaz Satış Fiyatları Sicili Oluşturulmasına Yönelik Bir Model Önerisi, Uzaktan Algılama ve CBS Sempozyumu, Eskişehir

UNECE, 1996. Land Administration Guidelines, United Nations Publication, ISBN 92-1-116644-6, New York and Geneva. UNECE, 2004, Guidelines on Real Property Units and Identifiers, United Nations Economic Commission for Europe, New York and Geneva, 68 pages. 
Molen, P. Oosterom, P.J.M. and Lemmen, C. (2004). "Remarks and Observations related to the further development of the Core Cadastral Domain Model', Joint 'FIG Commission 7' and 'COST G9' Workshop on Standardization of the Cadastral Domain, 9 and 10 December 2004, Germany.

Oosterom, P.J.M. and Lemmen, C., (2002). "Towards a standard for the cadastral domain: proposal to establish a core cadastral data model", Proceedings of the 3rd workshop and 4th MC meeting of the COST G9 action, 10-12 October, Delft, the Netherlands.

Yomralığlu, T. İnan, H. and Çete, M. (2007). "Dünyadaki Kadastral Sistemler İçin Ortak Bir Veri Modeli: Temel Kadastro Modeli (TKM)", Ulusal Coğrafi Bilgi Sistemleri Kongresi 30 Ekim -02 Kasım 2007, KTÜ, Trabzon. 